\title{
Spatial segregation of subordinate species is not controlled by the dominant species in a tropical coastal plant community
}

Mário L. Garbin ${ }^{1, *}$, Karlo G. Guidoni-Martins ${ }^{2}$, Renan K. Hollunder ${ }^{3}$, Pierre Mariotte ${ }^{4}$, Fabio R. Scarano ${ }^{5,6}$, Tatiana T. Carrijo ${ }^{3}$

${ }^{1}$ Universidade Vila Velha, Programa de Pós-Graduação em Ecologia de Ecossistemas, Laboratory of Functional Ecology, Rua Comissário José Dantas de Melo, s/n, Boa Vista, 29102-770, Vila Velha, Espírito Santo, Brasil

${ }^{2}$ Universidade Federal do Espírito Santo, Centro Universitário Norte do Espírito Santo, Rodovia BR 101 Norte, Km 60, Bairro Litorâneo, 29932-540, São Mateus, Espírito Santo, Brasil

${ }^{3}$ Universidade Federal do Espírito Santo, Centro de Ciências Agrárias, Departamento de Biologia, Laboratory of Botany, Rua Alto Universitário, s/n, Guararema, 29500-000, Alegre, ES, Brasil

${ }^{4}$ The University of Sydney, Center for Carbon, Water and Food, Biogeochemistry Group Room 204, 380 Werombi Rd, Camden NSW 2570

${ }^{5}$ Fundação Brasileira para o Desenvolvimento Sustentável, Rua Engenheiro Álvaro Niemeyer 76, São Conrado, 22610-180, Rio de Janeiro, RJ, Brasil

${ }^{6}$ Departamento de Ecologia, Universidade Federal do Rio de Janeiro, IB, CCS, Ilha do Fundão, 21941-970, Rio de Janeiro, RJ, Brasil

*Corresponding author: Mário L. Garbin; mlgarbin@gmail.com

Co-authors: K. Guidoni-Martins; karlogregorio@gmail.com

R. Hollunder; renanhollunder@gmail.com

P. Mariotte; pierre.mariotte@sydney.edu.au

F. Scarano; fscarano@fbds.org.br

T. Carrijo; tcarrijo@gmail.com 


\begin{abstract}
Subordinate species composition and distribution are regarded as a result of the dominant species structure. However, the spatial organization of subordinate species can also be related to dispersal abilities and interactions (competition and facilitation) within subordinate species. Here, we tested the influence of dominant species on subordinate species and examined traits of subordinate species together with their spatial patterns within a tropical coastal plant community. We hypothesized that the identity of dominant species determines subordinate abundance, and dispersal and persistence trait values variation, within coexisting subordinate species. Moreover, we expected that functionally similar subordinate species aggregate in space, regarding these values. We used the relative abundance of shrubs and trees from 83 vegetation patches in 2 hectares of Restinga vegetation in southeastern Brazil. We determined trait value dissimilarities between dominant and subordinate species and within subordinates, and tested for the effect of the dominant species on subordinate abundance and trait values variation. Spatial cross-correlation functions were estimated for the four most abundant subordinate species with spline and Moran's I cross-correlograms. Our results showed that dominant and subordinate species exhibit contrasted trait values for dispersal and persistence. However, the composition of subordinate species in patches and the variation in their functional traits were not controlled by the identity of dominant species. Surprisingly, subordinate species segregated in space. Spatial segregation was related to dissimilar trait values within subordinates. However, the identity of dominants and patch size had no control over subordinates' abundance. We suggest that such spatial segregation can result from competitive interactions. Dissimilar functional trait values within subordinate species seem to explain the spatial segregation of these species, principally led by differences in seed production and potential allelopathic interactions (e.g. Myrtaceae species). Therefore, independently of the identity of dominant species, subordinate species have a direct effect on the community composition of the Restinga vegetation. Together, our findings considerably increase knowledge on subordinate species in tropical plant communities and provide new insight into the potential role of subordinate species in community assembly.
\end{abstract}

Keywords: community assembly; plant-plant interactions; plant functional traits; spatial pattern; species coexistence; subordinate species. 


\section{Introduction}

Plant communities are generally composed by few dominant species and contain numerous co-existing subordinate species, which results in the observed lognormal species abundance distribution (Grime, 1998; Mariotte, 2014; Ulrich et al., 2010). Dominant species are the most competitive species and account for a high proportion of the biomass in the community, while less competitive subordinate species represent its most diverse component. According to the mass ratio hypothesis, dominant species are expected to drive ecosystem processes within the plant community (Grime, 1998). However, recent studies showed also that subordinate species are responsible for important ecosystem processes in grasslands (Mariotte et al., 2013) and maintain diversity in tropical communities (Garbin et al. 2014, 2012). Both species-groups seem functionally important in the plant community but the mechanism generating their relative abundance is still unclear.

Deterministic niche-based processes such as habitat filtering and niche differentiation have been suggested to explain species relative abundance and diversity (e.g., Cornwell and Ackerly, 2010). Habitat filtering selects individuals with suitable functional traits for a given habitat (Díaz et al., 1998), while niche differentiation select species with trait dissimilarities to promote the complementarity of resource use in space and time (Carroll et al., 2011). Both processes occur simultaneously in plant communities, and dispersal, abiotic factors and species interactions can act as filters (Kraft et al., 2015; Violle et al., 2012). Maire et al. (2012) showed that dominant species are mainly affected by habitat filtering whereas subordinate species are stabilized by niche differentiation (i.e. associated with dissimilar plant traits). Thus, subordinate species are expected to differ in plant functional traits and to be distributed in a patchy pattern in the plant community (Mariotte, 2014). Differences in trait values have been used to explain species coexistence of dominant and subordinate species in grasslands, while this phenomenon remains poorly studied in tropical forest and shrub communities. In the subtropics, fine-scale spatial aggregation $(10 \mathrm{~m}$ to $50 \mathrm{~m}$ ) of subordinate species can be explained by functional traits (Perry et al., 2013), especially the traits related to dispersal ability (Perry et al., 2013; Zhang et al., 2013). This interplay between dispersal traits and small-scale spatial aggregation makes the numerous subordinate plant species, growing under or nearby dominant species, an interesting model to understand plant coexistence.

Determining the functional dissimilarity between dominant and subordinate species and within 
subordinate species in tropical plant communities would considerably increase knowledge on the mechanisms involved in community assembly and diversity of these species rich ecosystems.

Since dominant species are more numerous, in most cases competitively superior, and possess the most suitable attributes (or trait values, sensu Violle et al., 2007) to persist in the ecosystem (i.e. habitat filtering), they play a key role in the structure of the plant community and exert strong controls over the assembly and the identity of subordinate species. For example, the architecture, phenology, genotype number and genotype variability of the foundation species (Gibson et al., 2012; Grime, 1998), as well as changes that these species induce in soil properties (Grman and Suding, 2010), have been shown to differentially affect the success of subordinate species in the community. In several plant communities, dominant species can act as nurse plants creating novel environments that alleviate stressful environmental conditions and provide structural support for many other species (Mcintire and Fajardo, 2014). This results in the well-documented clumped patterns of subordinate species around dominant nurse plants (see reviews in Callaway, 1995; Brooker et al., 2008; McIntire and Fajardo, 2014). However, the understanding of how the set of facilitated subordinate species coexists under the canopy of dominant nurses has seldom been evaluated.

Species interactions (competition and facilitation), environmental factors and dispersal directly influence spatial patterns in plant communities (Hubbell, 2001; Tirado and Pugnaire, 2005). Dispersal traits may explain small-scale spatial pattern of plant species (i.e. the aggregation of conspecific individuals) because species with similar attributes are expected to follow the same spatial patterns (Perry et al., 2013). Disentangling the relative roles of dispersal ability, local environmental conditions and species interactions in shaping local communities linked by dispersal is a central goal of ecology (Leibold et al., 2004; Lortie et al., 2004). Surprisingly, few studies addressed the role of dispersal traits in explaining the spatial organization of plant communities (Flinn et al., 2010). Highlighting the relationship between patch quality (defined by dominant species identity) and the dispersal traits of subordinate species would help understanding such spatial patterns in tropical communities. The study of spatial patterns, per se, offer clues to understand the underlying causes acting over the detected patterns (Legendre and Fortin, 1989; Maestre et al., 2005). Spatial patterns of individual species and co-occurrence patterns of any two species in space can be quantified 
with simple and cross-correlation functions (Fortin and Dale, 2005). The objective is to determine how much of the observed variation can be attributed to spatial factors and at which scales the variation is expressed (Robertson and Gross, 1994). The spatial pattern is then used to reveal the most important ecological processes responsible for the observed patterns (McIntire and Fajardo, 2009) because these process leave spatial signatures that serve as a basis for generating testable hypotheses about community assembly (Schenk et al., 2003). Despite the various drivers of spatial patterns in plant communities, we can use the spatial pattern itself as an indication of the most important processes in action in a given community.

In our study site, a tropical sandy coastal plain in Brazil ('restinga' thereof; see Scarano 2002), there is a history of investigation in this topic. Restinga vegetation consists of shrub patches, scattered over a matrix of white sand and herbaceous clumps. Each patch is dominated by a single dominant species and this ecosystem provides an excellent model to study the impacts of a single dominant species over subordinates. Dias et al. (2005) showed that architectural differences between dominant species (including one nurse plant) influence the density of understory juvenile species, a pattern that can be explained by differential attractiveness for dispersers. Subordinate species seem to present constant temporal patterns of seed rain throughout the year, while dominants disperse in well-defined and different periods (Braz and de Mattos, 2010). Dominant species, whether nurse plants or not, seem to have important filtering effects over subordinate species composition by attracting different seed dispersers and/or by creating different environmental conditions under their canopy. Therefore, the identity of dominant species might greatly influence the abundance and the identity of coexisting subordinate species, selecting for functionally dissimilar species in terms of dispersal and persistence. Moreover, Rosado and de Mattos (2010) found that differences in abundance between dominant and subordinate species can arise by differences in water stress tolerance. Slow growth species, with a conservative resource use, would attain dominance due to higher tolerance to water deficits. Subordinate species in the site can positively affect the diversity and abundance of climbing plants (Garbin et al., 2012), especially stem twining climbers (Garbin et al., 2014). The understanding of how subordinate species organize in space can thus provide clues about the mechanisms of community assembly in the restinga. However, the degree and scales of aggregation of subordinate species and the role of dispersal or persistence functional traits in explaining such aggregation patterns are unclear. 
The objectives of this study were threefold. First, we examined traits related to the dispersal and persistence (sensu Weiher et al., 1999) of both dominant and subordinate species in this same restinga site. We hypothesized that both species-groups exert contrasted trait values, regarding dispersal and persistence, which could explain the coexistence of a high number of species in the community. Secondly, we aimed to understand how dominant species identity influences the abundance, identity and attributes of subordinate species. We expected that tree dominance in each vegetation patch and patch size filter similar subordinate species regarding dispersal and persistence traits. Finally, we tested how subordinate species distribute spatially within the community, hypothesizing that, due to similar trait values for dispersal and persistence, these species show aggregated patterns.

\section{Methods}

Study site, sampling and selection of traits

The study was conducted in the Restinga de Jurubatiba National Park $\left(22^{\circ} 23^{\prime} \mathrm{S}\right.$, $41^{\circ} 45^{\prime} \mathrm{W}$, sea level), a sandy coastal plain plant community in southeast Brazil. Detailed information about the restinga vegetation, climate and structure can be found in Dias and Scarano (2007), Pimentel et al. (2007), and reviews of Scarano (2009; 2002). Restinga is the vegetation present in the Quaternary sandy coastal plains of Brazil and, in Rio de Janeiro State, consists of shrub patches scattered over a matrix of white sand and herbaceous clumps. The "patch quality" is defined by the identity of the dominant nurse species within the patch. Clusia hilariana Schltdl. (5-7 m tall) is generally the most abundant species while only a few patches are dominated by Protium icicariba (DC.) and Ocotea notata (Nees and C. Martius ex Nees) Mez. Clusia patches are taller, larger, and less dense than non-Clusia patches, which can lead to differences in attractiveness for seed dispersers as Clusia patches are richer in species than non-Clusia patches (Dias et al., 2005). Besides dominant nurse species, patches are colonized by numerous subordinate species (see Table 1).

We used data from 83 vegetation patches within a total area of 2 ha (100 m x $200 \mathrm{~m})$, each with a minimum diameter of $5 \mathrm{~m}$ and a central nurse tree (see Garbin et al., 2012). Smallest $\left(\mathrm{d}_{1}\right)$ and largest $\left(\mathrm{d}_{2}\right)$ patch diameters were measured in meters, and patch size was then estimated as $\pi\left(d_{1} / 2\right)\left(d_{2} / 2\right)$. Height of the vegetation was also recorded, along with the 
spatial coordinates using a Garmin Etrex GPS (Garmin International Inc., Kansas City, USA). Plant community composition was surveyed in patches using an adapted cover pin frame approach (Dias et al. 2005). Plots (1 $\mathrm{m} \times 2 \mathrm{~m}$ ) were installed in the center of each patch and we positioned a thin stick $(0.8 \mathrm{~cm}$ diameter $)$ vertically to record the identity and the number of times each species touched the stick. In each plot, this procedure was repeated 15 times at each $0.5 \mathrm{~m}$ interval, and these 15 samples were pooled to obtain the measure of species abundance. The relative abundances of shrub/tree species were then calculated for each patch by dividing the total number of touches of a species by the total number of touches of all species.

Dominant, subordinate and transient species (DST) were classified using cumulative relative abundances (Grime, 1998) and frequencies (Mariotte, 2014). We classified as dominant species the three overstory species Clusia hilariana, Protium icicariba and Ocotea notata, which are known to dominate patches in the field. Subordinate species were defined as those species above $2 \%$ in cumulative relative abundance and with a frequency of $20 \%$ or more in the patches. This method resulted in the determination of five subordinate species: Myrcia vittoriana, Myrsine parvifolia, Eugenia rotundifolia, Erythroxylum subsessile and Heisteria perianthomega. The other species were considered as transients (Table 1). To test whether dominant and subordinate species recorded in this study possess different strategies for dispersal and persistence, plant traits (fruit traits, seeds number, presence of latex, etc.) were collected (Table 2) for each species in the literature (Appendix Table S1). The choice of traits within these two strategies followed Weiher et al.'s (1999) recommendations to classify traits in challenges related to dispersal, persistence and establishment, and aims to give generality to the search of functional traits. The mechanisms related to dispersal and persistence were the capacity to hold/acquire space (e.g. life form, stem base), the ability to resist to mechanical damages (latex), potential reproduction output (number of seed per diaspore and number of diaspores per flower), and traits for animal or wind dispersal (aril, fruit type, dehiscence). These traits are expected to explain the response of subordinate species to dominants in terms of among-patch dispersal and persistence within patches. Qualitative multistate plant traits were binary-coded as dummy variables (Legendre and Legendre, 2012).

\section{Data analysis}

We began the analytical procedures by applying principal coordinate analysis (PCoA) in the plant trait matrix, using Jaccard as a similarity measure. Then, a PCA was run in a 
community-weighted means matrix (CWM) obtained by multiplying the relative abundances' matrix, after normalization within sampling units, by the plant traits' matrix of subordinate species. A canonical correspondence analysis (CCA) between the species x traits matrix constrained by a matrix of dominant/subordinate groups (Mariotte et al., 2013) coded as dummy variables (Legendre and Legendre, 2012) was run to test the significance of observed patterns. These procedures allowed us to detect trait dissimilarities between dominant and subordinate species. We ran a second PCoA, including only traits of subordinate species, to detect trait dissimilarities within subordinate species. A second PCA was then performed, using a relative abundances matrix composed of subordinate species only, after normalization. By plotting the identity of each dominant species (Clusia, Protium, Ocotea or mixed dominance) in each ordination procedure, we were able to detect patterns of association between subordinate and dominant species. A RDA (redundancy analysis) was used to test the association between subordinate species abundances and patch dominance identity after dummy variable coding for patch identity. To detect patterns of association between subordinate species and patch size, while controlling for spurious spatial effects, we performed the Dutilleul's modified $t$-test of correlation (Dutilleul et al., 1993). Finally, spatial univariate and cross-correlation functions were estimated between subordinate species with Moran's $I$ and spline cross-correlograms (BjØrnstad and Falck, 2001; Fortin and Dale, 2005). The spline correlogram is a continuous estimator of the covariance that allows the generalization of the discrete, most commonly used, correlogram (BjØrnstad and Falck, 2001). For comparative purposes, we used both approaches. The number of patches (18) with presence of the subordinate Heisteria perianthomega was not high enough to obtain reliable estimates of its spatial pattern. Pairwise zeros were deleted and the minimal number of pairs in a lag was 7 while the maximum was 148 . The total number of lags used in the univariate and crosscorrelograms was 20 , roughly corresponding to $50 \%$ (100 m) of the maximum amplitude (223.61 m). Uncertainty for splines and Moran's I cross-correlograms was estimated by bootstrap (10,000 iterations) and used to construct $95 \%$ envelopes for the splines and to estimate the significance for each lag in the Moran's I cross-correlograms.

All analyses were carried out in the R environment ( $\mathrm{R}$ Development Core Team, 2013): simple and constrained ordinations were run in the vegan package (Oksanen et al., 2013), Dutilleul's modified $t$-test was run in the SpatialPack package (Osorio et al., 2013), 
Moran's $I$ and spline univariate and cross-correlograms were run in the ncf package (BjØrnstad, 2013).

\section{Results}

Aril, fruit dehiscence, number of seeds per diaspore and number of diaspores per flower were the traits that better explained the differences between dominant and subordinate species (Fig. 1A). Subordinate species showed a lower number of seeds per diaspore and diaspores per flower and by contrast to dominant species, subordinates tended to have indehiscent fruits and do not have aril (Fig. 1A). Subordinate species principally differ from each other by the number of seeds per diaspore and presence of latex (Fig. 1B). Myrcia vittoriana had higher number of seeds per diaspore, exhibiting different trait values of seeds production from $E$. subsessile and $M$. parvifolia, while $E$. rotundifolia did not seem to possess different trait values from the three other species. Results of the CCA constraining plant traits by species-group confirmed that dominant and subordinate species are significantly different $(P<0.01 ;$ Appendix Fig. S2).

Patch identity, defined by the dominant species, had no influence on the mean trait values (CWM) among subordinate species (Fig. 2). Subordinate species showed great variation in abundance among patches but this was not related to patch identity (Fig. 3). Results of the RDA constraining species relative abundances by patch identity (i.e. dominant species) confirmed that dominant species had no control over the abundance of subordinate

species ( $P=0.70$; Appendix Fig. S3). Additionally, no relationships were observed between their relative abundance and patch area as shown by Dutilleul's correlation $t$-test $(M$. vittoriana: $-0.33, P=0.10 ; M$. parvifolia: $-0.27, P=0.29 ;$ E. rotundifolia: $-0.14, P=0.56 ; E$. subsessile: $-0.12, P=0.43 ; H$. perianthomega: $-0.16, P=0.49)$.

Univariate spatial patterns using both splines (continuous lines and respective envelopes) and Moran's I correlograms (with significance intervals depicted by black dots) showed significant aggregation for M. vittoriana and M. parvifolia (Fig. 4, main diagonal). For bivariate patterns, $M$. vittoriana was negatively associated (envelope is below the zero line for spline correlograms, lower triangular portion of Fig. 4) with both E. subsessile and $M$. parvifolia. Myrsine parvifolia was also negatively associated with E. rotundifolia. There was a 
tendency of positive spatial association (envelope is above the zero line for spline correlograms) between the two Myrtaceae species: E. rotundifolia and M. vittoriana. Significant intervals for bivariate Moran's I correlograms (upper triangular portion of Fig. 4) showed the same trend. Nevertheless, splines were readily interpretable due to the continuous function. The bubble graph showing relative abundances of species (Fig. 5) confirms this spatial pattern of association between the four subordinates, as detected by the spline and Moran's I correlograms. Areas with high abundance of Myrcia vittoriana (Fig. 5b) were almost unoccupied by Erythroxylum subsessile (Fig. 5a) and Myrsine parvifolia (Fig. 5c). By contrast, Eugenia rotundifolia (Fig. 5d) was coexisting in dense patch of Myrcia (Fig. 5b).

\section{Discussion}

We demonstrated that subordinate species differed from dominant species regarding dispersal and persistence trait values in a tropical coastal plant community. Dominant species

produced dehiscent fruits with aril and higher number of seeds, highlighting better abilities for seed production and dispersal than subordinate species. Dispersal promotes colonization of distant patches while abundant production of seeds promotes potential recruitment, increasing the chances of a competitive advantage within the patch. Therefore, along with higher capacity of water stress tolerance (Rosado and de Mattos, 2010), these specialized traits exerted by dominant species help explain why these species dominate patches of the Restinga vegetation. The main dominant species in the site, Clusia hilariana, also differ from the other species by showing higher germination rates under water deficits, even though the species' seeds dehydrate more rapidly than seeds of subordinate species (Braz and de Mattos, 2010), and most of the Clusia seedlings found in the restinga occur inside tank-bromeliads (Correia et al., 2010). We suggest that the contrasted trait values of subordinate species allow these species to coexist in the vegetation community through the use of different niches. Trait-based competitive differences between dominant and subordinate species have been similarly shown in grasslands with dominant species possessing attributes for rapid acquisition of resources (Mariotte et al., 2013). In forests, closely related understory species have been shown to be more strongly influenced by dominant overstory species than by competition among understory species (Sedio et al., 2012). The distinctive morphology and attributes of dominant species are expected to determine the identity and functional variation of coexisting 
subordinate species (Gibson et al., 2012; Grime, 1998). Facilitation studies have also emphasized the effects of nurse plants on subordinate species and, more recently, on how these effects vary along gradients of environmental variation (Brooker et al., 2008; Choler et al., 2001; Jia et al., 2011; Pellissier et al., 2010). While dominant species are expected to respond to environmental filters (Kumordzi et al., 2015; Maire et al., 2012), subordinate species would increase in abundance in response to local environmental conditions created by the dominant species. When explaining patterns of community organization it is often challenging to integrate the complexity of interactions (e.g. competition, facilitation) to draw general conclusions (Lortie et al., 2004). In our study, the singular structure of the coastal ecosystem, consisting of patches dominated by a nurse species, allowed testing for the effects of single dominant species. Moreover, different dominant species would attract different seed dispersers because of different architectural characteristics of these dominants (Dias et al., 2005). Our results show that the identity, abundance and variation in functional traits related to dispersal and establishment of subordinate species were not controlled by the identity of the dominant species, nor by the size of the patch. Thus, differences in dominance identity appeared to be less important than the relationships between subordinate species themselves.

There has been little discussion about whether the set of subordinate species growing under or nearby dominant nurse plants interacts with each other. The scope of this debate is, inevitably, about the role of subordinate species in community assembly. The Whittaker's (1965) separation of species into dominant, subordinate and transient species is a functional classification, and the focus of most functional studies is on dominant species due to an emphasis on the mass ratio hypothesis (Grime, 1998). A crucial question regarding subordinate species is about how different these species are, in responding to variations in the influence of dominant species, and how such differences can help explain patterns of species organization in high diversity systems. The degree at which functional species equivalence may be assumed within a functional group is one of the main discussions in the Hubbell's unified neutral theory of biodiversity and biogeography (Hubbell, 2005). Subordinate species did not assemble at random among patches and subordinate species with contrasting dispersal and persistence trait values occupied different patches, regardless of dominance identity. Given that the main dominant species at the site is also a nurse plant (Correia et al., 2010; Dias and Scarano, 2007), our study suggests that the spatial expansion of the niche caused by facilitation (Bruno et al., 2003) may be further counterbalanced by negative interactions 
among subordinate species. Habitat variability (in our case, patch quality) can lead to both, segregation and aggregation of species, while competition and positive interactions lead to segregation or aggregation respectively (Götzenberger et al., 2012). We found that the local aggregation (driven by positive interactions) in patches can be affected by negative interactions (segregation) between subordinate species, while patch quality (dominance identity) had no effect on such segregation. Therefore, our findings demonstrate that subordinate species are also key players in plant communities and not just a mere resultant of the dominant species influences.

We found that subordinate species principally segregate in space. Both stochastic (chance events of colonization) and deterministic (species interactions) processes can explain the observed patterns of subordinate species segregation in space. Spatial aggregation of conspecific plants may result from dispersal limitation (Vogt et al., 2010), that is defined as the failure of a species to reach or establish on all favorable sites for their growth or survival. However, besides low dispersal abilities (e.g. functional traits), all subordinate species studied here showed a relatively high frequency of occurring in patches (between 25\% to 53\%) and were interspersed among patches within the 2 ha area (see Fig. 5), though in an aggregated fashion. When describing functional traits among subordinate species, we found that the five subordinate species exhibit different trait values for seed production with $M$. vittoriana producing the double of seeds per diaspore than both E. subsessile and M. parvifolia. This awards to the former species a potential competitive advantage to persist within a patch. Myrsine parvifolia and E. subsessile differed on other traits; $M$. parvifolia, with a dioecious reproduction (ensuring cross-pollination) and E. subsessile, by the production of latex, which is known as a defense mechanism against herbivores. The two other subordinate species, $E$. rotundifolia and $H$. perianthomega did not specifically differ from the other on trait values for dispersal and persistence. The detected patterns of spatial organization between subordinate species suggest that dispersal traits play a role in explaining how subordinates coexist under the canopy of the dominant plants even at the relatively small scale of the study. However, the spatial patterns of species' segregation observed here suggest that other mechanisms may also be involved. Interestingly, the spatial segregation between subordinate species seems to correspond to the trait dissimilarities exhibited by subordinate species, with E. subsessile and M. parvifolia absent from patches colonized by $M$. vittoriana, the most productive seeder. Moreover, we found a positive association between the Myrtaceae species (M. vittoriana and 
E. rotundifolia), which segregated from the other subordinate species. This segregation of Myrtaceae species can be due to allelopathic interactions (see Inderjit and Weiner 2001), since there are several evidences of allelopathic effects caused by Myrtaceae species, especially by Eucalyptus spp. (Espinosa-García et al., 2008; Fang et al., 2008; May and Ash, 1990; Nishimura et al., 1984), and Myrcia spp. (Imatomi et al., 2013a, 2013b). Our results suggest that, through better seed production abilities and potential allelopathic effects, $M$. vittoriana is more able to colonize and persist in patches of the Restinga vegetation, excluding the other subordinate species. Priority effects, initial colonization of a given species in a habitat affecting the subsequent species (Fukami, 2004; Shulman et al., 1983), can have strong effects on the assembly of plant communities (Fukami et al., 2005; von Gillhaussen et al., 2014). Priority effects can explain changes in species composition in space (i.e. beta diversity), when environmental conditions are similar (Chase and Myers, 2011; Chase, 2003) and we suggest that $M$. vittoriana might influence the assemblage of the other species. Consequently, the assembly history of subordinate species in different patches is expected to determine local community composition, leading to different stable states despite the dominant species identity.

\section{Conclusion}

Contrary to our hypothesis, subordinate species segregated in space and occupied different patches, but this was not controlled by the identity of the dominant species, nor by the size of the patch. Our study also demonstrates that dominant and subordinate species exhibit different functional trait values for dispersal and persistence, which helps explain their coexistence within this restinga. Surprisingly, subordinate species specialized in different strategies related to seed production, reproduction or defense mechanisms, which explain their spatial patterns within the vegetation. Our findings considerably increase knowledge on subordinate species in tropical communities and provide new insight into the potential role of subordinate species in ecosystem functioning. Even if the number of studies on subordinate species in tropical communities is limited, there is growing evidence pointing to a crucial importance of these species in community assembly and ecosystem processes (Mariotte, 2014). For example, in previous studies, we showed that the presence of the subordinate species E. subsessile in vegetation patches increased the diversity of climbing plants (Garbin 
et al., 2012) and that such positive effect was more evident on stem-twining climbers (Garbin et al., 2014). The spatial segregation between E. subsessile and M. vittoriana that we observed in this study calls attention for the intricate relationships affecting the diversity of climbers. Indeed, if E. subsessile is restricted to the patches where M. vittoriana is absent or in low abundance, this would have also direct impact on the diversity of climbing plants. Independently of the identity of dominant species, subordinate species seem to have direct effect on the community composition of the Restinga vegetation and future studies should evaluate whether the patterns detected here apply to larger spatial extents and in other similar communities. For the latter, it will be necessary to take into account the high morphophysiological plasticity of restinga species that enables the colonization of highly variable extreme habitats (Scarano et al., 2009). Moreover, the study of subordinate species is recent, and further investigations are needed to determine the role of this species-group in the biodiversity and the functioning of these ecosystems and to better understand patterns of functional diversity.

\section{Acknowledgements}

We are grateful to Andrea Sánchez-Tapia and Jerônimo B.B. Sansevero for kindly allowing us to use raw data from previous studies at the site and to Bruno H.P. Rosado and an anonymous reviewer whose comments helped improving the manuscript. We would like to thank FAPES, CNPq and Capes (Espírito Santo State Research Agency/Brazilian Research Agencies), which granted fellowships to M.L. Garbin and K.G.Guidoni-Martins, and an undergraduate scholarship to R.K. Hollunder. P. Mariotte acknowledges the support of the Swiss National Science Foundation (P300P3_154648).

\section{References}

BjØrnstad, O.N., 2013. ncf: spatial nonparametric covariance functions. R package version 1.1-5. http://CRAN.R-project.org/package=ncf.

BjØrnstad, O.N., Falck, W., 2001. Nonparametric spatial covariance functions: Estimation and testing. Environ. Ecol. Stat. 8, 53-70. doi:10.1023/A:1009601932481

Braz, M.I.G., de Mattos, E.A., 2010. Seed Dispersal Phenology and Germination Characteristics of a Drought-Prone Vegetation in Southeastern Brazil. Biotropica 42, 
327-335. doi:10.1111/j.1744-7429.2009.00602.x

Brooker, R.W., Maestre, F.T., Callaway, R.M., Lortie, C.L., Cavieres, L. a., Kunstler, G., Liancourt, P., Tielbörger, K., Travis, J.M.J., Anthelme, F., Armas, C., Coll, L., Corcket, E., Delzon, S., Forey, E., Kikvidze, Z., Olofsson, J., Pugnaire, F., Quiroz, C.L., Saccone, P., Schiffers, K., Seifan, M., Touzard, B., Michalet, R., 2008. Facilitation in plant communities: the past, the present, and the future. J. Ecol. 96, 18-34. doi:doi:10.1111/j.1365-2745.2007.01295.x

Bruno, J.F., Stachowicz, J.J., Bertness, M.D., 2003. Inclusion of facilitation into ecological theory. Trends Ecol. Evol. 18, 119-125. doi:10.1016/S0169-5347(02)00045-9

Bruun, H.H., Poschlod, P., 2006. Why are small seeds dispersed through animal guts: large numbers or seed size per se? Oikos 113, 402-411. doi:10.1111/j.2006.0030-1299.14114.x

Burd, M., Ashman, T.L., Campbell, D.R., Dudash, M.R., Johnston, M.O., Knight, T.M., Mazer, S.J., Mitchell, R.J., Steets, J. a., Vamosi, J.C., 2009. Ovule number per flower in a world of unpredictable pollination. Am. J. Bot. 96, 1159-1167. doi:10.3732/ajb.0800183

Carroll, I.T., Cardinale, B.J., Nisbet, R.M., 2011. Niche and fitness differences relate the maintenance of diversity to ecosystem function of diversity relate the maintenance differences Niche and fitness to ecosystem function. Ecology 92, 1157-1165. doi:10.1890/10-0302.1

Castanho, C.T., Oliveira, A.A., Prado, P.I., 2012. The importance of plant life form on spatial associations along a subtropical coastal dune gradient. J. Veg. Sci. 23, 952-961. doi:10.1111/j.1654-1103.2012.01414.x

Chase, J.M., 2003. Community assembly: when should history matter? Oecologia 136, 48998. doi:10.1007/s00442-003-1311-7

Chase, J.M., Myers, J.A., 2011. Disentangling the importance of ecological niches from stochastic processes across scales. Philos. Trans. R. Soc. Lond. B. Biol. Sci. 366, 235163. doi:10.1098/rstb.2011.0063

Choler, P., Michalet, R., Callaway, R.M., 2001. Facilitation and competition on gradients in alpine plant communities. Ecology 82, 3295-3308. doi:10.1890/00129658(2001)082[3295:FACOGI]2.0.CO;2

Cornelissen, J.H.C., Lavorel, S., Garnier, E., Diaz, S., Buchmann, N., Gurvich, D.E., Reich, P.B., ter Steege, H., Morgan, H.D., van der Heijden, M.G.A., Pausas, J.G., Poorter, H., 2003. A handbook of protocols for standardised and easy measurement of plant functional traits worldwide. Aust. J. Bot. 51, 335-380. doi:10.1071/bt02124

Cornwell, W.K., Ackerly, D.D., 2010. A link between plant traits and abundance: evidence from coastal California woody plants. J. Ecol. 98, 814-821. doi:10.1111/j.1365- 
2745.2010.01662.x

Correia, C., Dias, A., Scarano, F., 2010. Plant-plant associations and population structure of four woody plant species in a patchy coastal vegetation of Southeastern Brazil. Brazilian J. Bot. 33, 607-613.

Dias, A.T.C., Scarano, F.R., 2007. Clusia as Nurse Plant, in: Lüttge, U. (Ed.), Clusia: A Woody Neotropical Genus of Remarkable Plasticity and Diversity, Ecological Studies. Springer Berlin Heidelberg, Berlin, Heidelberg, pp. 55-71. doi:10.1007/978-3-54037243-1_5

Dias, A.T.C., Zaluar, H.L.T., Ganade, G., Scarano, F.R., 2005. Canopy composition influencing plant patch dynamics in a Brazilian sandy coastal plain. J. Trop. Ecol. 21, 343-347. doi:10.1017/S0266467404002226

Díaz, S., Cabido, M., Casanoves, F., 1998. Plant functional traits and environmental filters at a regional scale. J. Veg. Sci. 9, 113-122. doi:10.2307/3237229

Duarte, L. da S., Carlucci, M.B., Hartz, S.M., Pillar, V.D., 2007. Plant dispersal strategies and the colonization of Araucaria forest patches in a grassland-forest mosaic. J. Veg. Sci. 18, 847-858. doi:10.1111/j.1654-1103.2007.tb02601.x

Dutilleul, P., Clifford, P., Richardson, S., Hemon, D., 1993. Modifying the t Test for Assessing the Correlation Between Two Spatial Processes. Biometrics 49, 305. doi: $10.2307 / 2532625$

Espinosa-García, F.J.F., Martínez-Hernández, E., Quiroz-Flores, A., 2008. Allelopathic potential of Eucalyptus spp plantations on germination and early growth of annual crops. Allelopath. J. 21, 25-37.

Fang, B., Yu, S., Wang, Y., Qiu, X., Cai, C., Liu, S., 2008. Allelopathic effects of Eucalyptus urophylla on ten tree species in south China. Agrofor. Syst. 76, 401-408. doi:10.1007/s10457-008-9184-8

Flinn, K.M., Gouhier, T.C., Lechowicz, M.J., Waterway, M.J., 2010. The role of dispersal in shaping plant community composition of wetlands within an old-growth forest. J. Ecol. 98, 1292-1299. doi:10.1111/j.1365-2745.2010.01708.x

Fortin, M.-J., Dale, M.R.T., 2005. Spatial analysis: a guide for ecologists. Cambridge University Press, Cambridge.

Fukami, T., 2004. Assembly history interacts with ecosystem size to influence species diversity. Ecology 85, 3234-3242. doi:10.1890/04-0340

Fukami, T., Martijn Bezemer, T., Mortimer, S.R., Putten, W.H., 2005. Species divergence and trait convergence in experimental plant community assembly. Ecol. Lett. 8, 1283-1290. doi:10.1111/j.1461-0248.2005.00829.x 
Galetti, M., Pizo, M.A., Morellato, L.P.C., 2011. Diversity of functional traits of fleshy fruits in a species-rich Atlantic rain forest. Biota Neotrop. 11, 181-194.

Garbin, M.L., Carrijo, T.T., Sansevero, J.B.B., Sánchez-Tapia, A., Scarano, F.R., 2012. Subordinate, not dominant, woody species promote the diversity of climbing plants. Perspect. Plant Ecol. Evol. Syst. 14, 257-265. doi:10.1016/j.ppees.2012.03.001

Garbin, M.L., Sánchez-Tapia, A., Carrijo, T.T., Sansevero, J.B.B., Scarano, F.R., 2014. Functional traits behind the association between climbers and subordinate woody species. J. Veg. Sci. 25, 715-723. doi:10.1111/jvs.12140

Gibson, D.J., Allstadt, A.J., Baer, S.G., Geisler, M., 2012. Effects of foundation species genotypic diversity on subordinate species richness in an assembling community. Oikos 121, 496-507. doi:10.1111/j.1600-0706.2011.19447.x

Götzenberger, L., de Bello, F., Bråthen, K.A., Davison, J., Dubuis, A., Guisan, A., Lepš, J., Lindborg, R., Moora, M., Pärtel, M., Pellissier, L., Pottier, J., Vittoz, P., Zobel, K., Zobel, M., 2012. Ecological assembly rules in plant communities-approaches, patterns and prospects. Biol. Rev. doi:10.1111/j.1469-185X.2011.00187.x

Grime, J.P., 1998. Benefits of plant diversity to ecosystems: immediate, filter and founder effects. J. Ecol. 86, 902-910. doi:10.1046/j.1365-2745.1998.00306.x

Grman, E., Suding, K.N., 2010. Within-Year Soil Legacies Contribute to Strong Priority Effects of Exotics on Native California Grassland Communities. Restor. Ecol. 18, 664670. doi:10.1111/j.1526-100X.2008.00497.x

Hubbell, S.P., 2001. The unified neutral theory of biodiversity and biogeography. Princeton University Press, Princeton.

Hubbell, S.P., 2005. Neutral theory in community ecology and the hypothesis of functional equivalence. Funct. Ecol. 19, 166-172. doi:10.1111/j.0269-8463.2005.00965.x

Imatomi, M., Novaes, P., Gualtieri, S.C.J., 2013a. Interspecific variation in the allelopathic potential of the family Myrtaceae. Acta Bot. Brasilica 27, 54-61. doi:10.1590/S010233062013000100008

Imatomi, M., Novaes, P., Matos, A.P., Gualtieri, S.C.J.J., Molinillo, J.M.G.G., Lacret, R., Varela, R.M., Macías, F. a., 2013b. Phytotoxic effect of bioactive compounds isolated from Myrcia tomentosa (Myrtaceae) leaves. Biochem. Syst. Ecol. 46, 29-35. doi:10.1016/j.bse.2012.09.005

Inderjit, Weiner, J., 2001. Plant allelochemical interference or soil chemical ecology? Perspect. Plant Ecol. Evol. Syst. 4, 3-12. doi:10.1078/1433-8319-00011

Jia, X., Dai, X.-F., Shen, Z.-X., Zhang, J.-Y., Wang, G.-X., 2011. Facilitation can maintain clustered spatial pattern of plant populations during density-dependent mortality: insights 
from a zone-of-influence model. Oikos 120, 472-480. doi:10.1111/j.16000706.2010.18674.x

Jones, N.T., Germain, R.M., Grainger, T.N., Hall, A.M., Baldwin, L., Gilbert, B., 2015. Dispersal mode mediates the effect of patch size and patch connectivity on metacommunity diversity. J. Ecol. 103, 935-944. doi:10.1111/1365-2745.12405

Konno, K., 2011. Plant latex and other exudates as plant defense systems: Roles of various defense chemicals and proteins contained therein. Phytochemistry 72, 1510-1530. doi:10.1016/j.phytochem.2011.02.016

Kraft, N.J.B., Adler, P.B., Godoy, O., James, E.C., Fuller, S., Levine, J.M., 2015. Community assembly, coexistence and the environmental filtering metaphor. Funct. Ecol. 29, 592599. doi:10.1111/1365-2435.12345

Kumordzi, B.B., Wardle, D. a., Freschet, G.T., 2015. Plant assemblages do not respond homogenously to local variation in environmental conditions: Functional responses differ with species identity and abundance. J. Veg. Sci. 26, 32-45. doi:10.1111/jvs.12218

Legendre, P., Fortin, M.J., 1989. Spatial pattern and ecological analysis. Vegetatio 80, 107138. doi:10.1007/BF00048036

Legendre, P., Legendre, L., 2012. Numerical Ecology, Third. ed. Elsevier, Amsterdan.

Leibold, M. a., Holyoak, M., Mouquet, N., Amarasekare, P., Chase, J.M., Hoopes, M.F., Holt, R.D., Shurin, J.B., Law, R., Tilman, D., Loreau, M., Gonzalez, A., Letters, E., 2004. The metacommunity concept: a framework for multi-scale community ecology. Ecol. Lett. 7, 601-613. doi:10.1111/j.1461-0248.2004.00608.x

Leishman, M.R., 2001. Does the seed size/number trade-off model determine plant community structure? An assessment of the model mechanisms and their generality. Oikos 93, 294302. doi:10.1034/j.1600-0706.2001.930212.x

Lortie, C.J., Brooker, R.W., Choler, P., Kikvidze, Z., Michalet, R., Pugnaire, F.I., Callaway, R.M., 2004. Rethinking plant community theory. Oikos 107, 433-438. doi:10.1111/j.0030-1299.2004.13250.x

Mabry, C., Ackerly, D., Gerhardt, F., 2000. Landscape and species-level distribution of morphological and life history traits in a temperate woodland flora. J. Veg. Sci. 11, 213224. doi: $10.2307 / 3236801$

Mabry, C.M., Fraterrigo, J.M., 2009. Species traits as generalized predictors of forest community response to human disturbance. For. Ecol. Manage. 257, 723-730. doi:10.1016/j.foreco.2008.10.002

Maestre, F.T., Rodriguez, F., Bautista, S., Cortina, J., Bellot, J., 2005. Spatial associations and patterns of perennial vegetation in a semi-arid steppe: a multivariate geostatistics 
approach. Plant Ecol. 179, 133-147. doi:10.1007/s11258-004-4641-6

Maire, V., Gross, N., Börger, L., Proulx, R., Wirth, C., Pontes, L. da S., Soussana, J.F., Louault, F., 2012. Habitat filtering and niche differentiation jointly explain species relative abundance within grassland communities along fertility and disturbance gradients. New Phytol. 196, 497-509. doi:10.1111/j.1469-8137.2012.04287.x

Mariotte, P., 2014. Do subordinate species punch above their weight? Evidence from aboveand below-ground. New Phytol. 203, 16-21. doi:10.1111/nph.12789

Mariotte, P., Vandenberghe, C., Meugnier, C., Rossi, P., Bardgett, R.D., Buttler, A., 2013. Subordinate plant species impact on soil microbial communities and ecosystem functioning in grasslands: Findings from a removal experiment. Perspect. Plant Ecol. Evol. Syst. 15, 77-85. doi:10.1016/j.ppees.2012.12.003

May, F., Ash, J., 1990. An Assessment of the Allelopathic Potential of Eucalyptus. Aust. J. Bot. 38, 245. doi:10.1071/BT9900245

McIntire, E.J.B., Fajardo, A., 2009. Beyond description: the active and effective way to infer processes from spatial patterns. Ecology 90, 46-56. doi:10.1890/07-2096.1

Mcintire, E.J.B., Fajardo, A., 2014. Facilitation as a ubiquitous driver of biodiversity. New Phytol. 201, 403-416. doi:10.1111/nph.12478

Müller, S.C., Overbeck, G.E., Pfadenhauer, J., Pillar, V.D., 2007. Plant functional types of woody species related to fire disturbance in forest-grassland ecotones. Plant Ecol. 189, 114. doi:10.1007/s11258-006-9162-z

Nishimura, H., Nakamura, T., Mizutani, J., 1984. Allelopathic effects of p-menthane-3,8-diols in Eucalyptus citriodora. Phytochemistry 23, 2777-2779. doi:10.1016/00319422(84)83014-9

Oksanen, J., Blanchet, F.G., Kindt, R., Legendre, P., Minchin, P.R., O’Hara, R.G., Simpson, G.L., Solymos, P., Stevens, M.H.H., Wagner, H., 2013. vegan: Community Ecology Package. $\mathrm{R}$ package version 2.0-10. http://CRAN.R-project.org/package=vegan.

Osorio, F., Vallejos, R., Cuevas, F., 2013. SpatialPack: Package for analysis of spatial data. R package version 0.2. http://CRAN.R-project.org/package=SpatialPack.

Pellissier, L., Anne Bråthen, K., Pottier, J., Randin, C.F., Vittoz, P., Dubuis, A., Yoccoz, N.G., Alm, T., Zimmermann, N.E., Guisan, A., 2010. Species distribution models reveal apparent competitive and facilitative effects of a dominant species on the distribution of tundra plants. Ecography (Cop.). 33, 1004-1014. doi:10.1111/j.1600-0587.2010.06386.x

Pérez-Harguindeguy, N., Díaz, S., Garnier, E., Lavorel, S., Poorter, H., Jaureguiberry, P., Bret-Harte, M.S., Cornwell, W.K., Craine, J.M., Gurvich, D.E., Urcelay, C., Veneklaas, E.J., Reich, P.B., Poorter, L., Wright, I.J., Ray, P., Enrico, L., Pausas, J.G., de Vos, A.C., 
Buchmann, N., Funes, G., Quétier, F., Hodgson, J.G., Thompson, K., Morgan, H.D., ter Steege, H., Sack, L., Blonder, B., Poschlod, P., Vaieretti, M. V, Conti, G., Staver, A.C., Aquino, S., Cornelissen, J.H.C., Vos, A.C. De, Buchmann, N., Funes, G., Hodgson, J.G., Thompson, K., Morgan, H.D., Steege, H., Heijden, M.G.A. Van Der, Sack, L., Blonder, B., Poschlod, P., Vaieretti, M. V, Conti, G., Staver, A.C., Aquino, S., Cornelissen, J.H.C., 2013. New handbook for standardised measurement of plant functional traits worldwide. Aust. J. Bot. 61, 167. doi:10.1071/BT12225

Perry, G.L.W., Enright, N.J., Miller, B.P., Lamont, B.B., 2013. Do plant functional traits determine spatial pattern? A test on species-rich shrublands, Western Australia. J. Veg. Sci. 24, 441-452. doi:10.1111/j.1654-1103.2012.01476.x

Pimentel, M.C.P., Barros, M.J., Cirne, P., Mattos, E.A. de, Oliveira, R.C., Pereira, M.C.A., Scarano, F.R., Zaluar, H.L.T., Araujo, D.S.D., 2007. Spatial variation in the structure and floristic composition of "restinga" vegetation in southeastern Brazil. Rev. Bras. Botânica 30, 543-551. doi:10.1590/S0100-84042007000300018

R-Development-Core-Team, 2014. R Foundation for Statistical Computing, Vienna, Austria. URL http://www.R-project.org/.

Réjou-Méchain, M., Cheptou, P.-O., 2015. High incidence of dioecy in young successional tropical forests. J. Ecol. 103, 725-732. doi:10.1111/1365-2745.12393

Robertson, G.P., Gross, K.L., 1994. Assessing the heterogeneity of belowground resources: quantifying pattern and scale, in: Pearcy, R.W. (Ed.), Exploitation of Environmental Heterogeneity by Plants: Ecophysiological Processes above- and Belowground. Academic Press, San Diego, pp. 237-253.

Rosado, B.H.P., de Mattos, E.A., 2010. Interspecific variation of functional traits in a CAMtree dominated sandy coastal plain. J. Veg. Sci. 21, 43-54. doi:10.1111/j.16541103.2009.01119.x

Scarano, F.R., 2002. Structure, function and floristic relationships of plant communities in stressful habitats marginal to the Brazilian Atlantic rainforest. Ann. Bot. 90, 517-524. doi:10.1093/aob/mcf189

Scarano, F.R., 2009. Plant communities at the periphery of the Atlantic rain forest: Rarespecies bias and its risks for conservation. Biol. Conserv. 142, 1201-1208. doi:10.1016/j.biocon.2009.02.027

Scarano, F.R., Barros, C.F., Loh, R.K.T. de M., de Mattos, E.A., Wendt, T., 2009. Plant morpho-physiological variation under distinct environmental extremes in restinga vegetation. Rodriguesia 60, 221-235.

Schenk, H.J., Holzapfel, C., Hamilton, J.G., Mahall, B.E., 2003. Spatial ecology of a small desert shrub on adjacent geological substrates. J. Ecol. 91, 383-395. doi:10.1046/j.1365- 
2745.2003.00782.x

Sedio, B.E., Wright, S.J., Dick, C.W., 2012. Trait evolution and the coexistence of a species swarm in the tropical forest understorey. J. Ecol. 100, 1183-1193. doi:10.1111/j.13652745.2012.01993.x

Shulman, M.J., Ogden, J.C., Ebersole, J.P., McFarland, W.N., Miller, S.L., Wolf, N.G., 1983. Priority Effects in the Recruitment of Juvenile Coral Reef Fishes. Ecology 64, 1508. doi:10.2307/1937505

Tirado, R., Pugnaire, F.I., 2005. Community structure and positive interactions in constraining environments. Oikos 111, 437-444. doi:10.1111/j.1600-0706.2005.14094.x

Ulrich, W., Ollik, M., Ugland, K.I., 2010. A meta-analysis of species-abundance distributions. Oikos 119, 1149-1155. doi:10.1111/j.1600-0706.2009.18236.x

Vamosi, J.C., Vamosi, S.M., 2004. The role of diversification in causing the correlates of dioecy. Evolution (N. Y). 58, 723. doi:10.1554/03-312

Vamosi, S.M., Queenborough, S. a., 2010. Breeding systems and phylogenetic diversity of seed plants along a large-scale elevational gradient. J. Biogeogr. 37, 465-476. doi:10.1111/j.1365-2699.2009.02214.x

Violle, C., Enquist, B.J., McGill, B.J., Jiang, L., Albert, C.H., Hulshof, C., Jung, V., Messier, J., 2012. The return of the variance: Intraspecific variability in community ecology. Trends Ecol. Evol. 27, 244-252. doi:10.1016/j.tree.2011.11.014

Violle, C., Navas, M.-L., Vile, D., Kazakou, E., Fortunel, C., Hummel, I., Garnier, E., 2007. Let the concept of trait be functional! Oikos 116, 882-892. doi:10.1111/j.2007.00301299.15559.x

Vogt, D.R., Murrell, D.J., Stoll, P., 2010. Testing spatial theories of plant coexistence: no consistent differences in intra- and interspecific interaction distances. Am. Nat. 175, 7384. doi:10.1086/648556

von Gillhaussen, P., Rascher, U., Jablonowski, N.D., Plückers, C., Beierkuhnlein, C., Temperton, V.M., 2014. Priority effects of time of arrival of plant functional groups override sowing interval or density effects: a grassland experiment. PLoS One 9, e86906. doi:10.1371/journal.pone.0086906

Weiher, E., van der Werf, A., Thompson, K., Roderick, M., Garnier, E., Eriksson, O., 1999. Challenging Theophrastus: A common core list of plant traits for functional ecology. J. Veg. Sci. 10, 609-620. doi:10.2307/3237076

Westoby, M., Jurado, E., Leishman, M., 1992. Comparative evolutionary ecology of seed size. Trends Ecol. Evol. 7, 368-372. doi:10.1016/0169-5347(92)90006-W 
Whittaker, R.H., 1965. Dominance and Diversity in Land Plant Communities: Numerical relations of species express the importance of competition in community function and evolution. Science 147, 250-60. doi:10.1126/science.147.3655.250

Zhang, Z., Hu, G., Zhu, J., Ni, J., 2013. Aggregated spatial distributions of species in a subtropical karst forest, southwestern China. J. Plant Ecol. 6, 131-140. doi:10.1093/jpe/rts027 
Table 1. Dominant, subordinate (boldface), and transient shrub and tree species in 2 ha of open Clusia Restinga vegetation followed by the species family, code, relative abundance, cumulative relative abundance, frequency and DST (dominant, subordinate or transient) classification. References, used for building the traits' matrix, are detailed in Appendix 1.

\begin{tabular}{|c|c|c|c|c|c|c|c|}
\hline Plant species & Family & Code & $\begin{array}{c}\text { Relative } \\
\text { abundance }\end{array}$ & $\begin{array}{c}\text { Cumulative } \\
\text { relative } \\
\text { abundance }(\%)\end{array}$ & $\begin{array}{l}\text { Frequency } \\
\qquad(\%)\end{array}$ & DST & References \\
\hline Clusia hilariana & Clusiaceae & Chi & 37.11 & 100 & 66 & $\mathrm{D}$ & $5,6,7$ \\
\hline Protium icicariba & Burseraceae & Pic & 20.12 & 62.89 & 63 & $\mathrm{D}$ & 27,28 \\
\hline Ocotea notata & Lauraceae & Ono & 8.44 & 42.77 & 41 & $\mathrm{D}$ & $23,24,25$ \\
\hline Erythroxylum subsessile & Erythroxylaceae & Esu & 6.27 & 34.34 & 53 & $\mathbf{S}$ & 10,11 \\
\hline Myrcia vittoriana & Myrtaceae & Mvi & 5.42 & 28.07 & 28 & $\mathbf{S}$ & 19 \\
\hline Tapirira guianensis & Anacardiaceae & Tgu & 3.49 & 22.65 & 10 & $\mathrm{~T}$ & 29 \\
\hline Heisteria perianthomega & Olacaceae & Hре & 2.77 & 19.16 & 22 & $\mathbf{S}$ & 16 \\
\hline Myrsine parvifolia & Primulaceae & Мрa & 2.05 & 16.39 & 25 & $\mathbf{S}$ & 20 \\
\hline Eugenia rotundifolia & Myrtaceae & Ero & 1.93 & 14.34 & 25 & $\mathbf{S}$ & 14,15 \\
\hline Coccoloba declinata & Polygonaceae & Cde & 1.57 & 12.41 & 11 & $\mathrm{~T}$ & 8,9 \\
\hline Neomitranthes obscura & Myrtaceae & Nob & 1.57 & 10.84 & 10 & $\mathrm{~T}$ & 22 \\
\hline Calyptranthes brasiliensis & Myrtaceae & Cbr & 1.57 & 9.28 & 16 & $\mathrm{~T}$ & 2 \\
\hline Xylopia ochrantha & Annonaceae & Xoc & 1.45 & 7.71 & 17 & $\mathrm{~T}$ & 33 \\
\hline Capparis flexuosa & Capparidaceae & Cfl & 1.20 & 6.27 & 11 & $\mathrm{~T}$ & 3,4 \\
\hline Ouratea cuspidata & Ochnaceae & Ocu & 1.20 & 5.06 & 11 & $\mathrm{~T}$ & 26 \\
\hline Ternstroemia brasiliensis & Pentaphylacaceae & Tbr & 0.96 & 3.86 & 12 & $\mathrm{~T}$ & $30,31,32$ \\
\hline Amaioua intermedia & Rubiaceae & Ain & 0.84 & 2.89 & 7 & $\mathrm{~T}$ & 1 \\
\hline Myrcia multiflora & Myrtaceae & $\mathrm{Mmu}$ & 0.60 & 2.05 & 7 & $\mathrm{~T}$ & 18 \\
\hline Eugenia punicifolia & Myrtaceae & Epu & 0.60 & 1.45 & 6 & $\mathrm{~T}$ & 12,13 \\
\hline Heteropterys coleoptera & Malpighiaceae & Hсо & 0.60 & 0.84 & 11 & $\mathrm{~T}$ & 17 \\
\hline Myrsine umbellata & Primulaceae & Mum & 0.24 & 0.24 & 7 & $\mathrm{~T}$ & 21 \\
\hline
\end{tabular}


Table 2. Functional traits (dispersal and persistence) used for the characterization of dominant and subordinate woody species in the Restinga vegetation.

\begin{tabular}{|c|c|c|c|c|c|c|}
\hline Trait & Code & Type & States & Function & Mechanism & References \\
\hline Fruit type & $f t$ & Qualitative & Dry; fleshy & Dispersal & $\begin{array}{l}\text { Animal or wind } \\
\text { dispersal }\end{array}$ & $\begin{array}{l}\text { Cornelissen et al. (2003), Galetti et } \\
\text { al. (2011), Jones et al. ( 2015) }\end{array}$ \\
\hline Fruit dehiscence & $f d$ & Qualitative & $\begin{array}{l}\text { Dehiscent; } \\
\text { indehiscent }\end{array}$ & Dispersal & $\begin{array}{l}\text { Associated with } \\
\text { different life } \\
\text { form groups, } \\
\text { disturbances }\end{array}$ & $\begin{array}{l}\text { Mabry et al. (2000), Mabry and } \\
\text { Fraterrigo (2009) }\end{array}$ \\
\hline $\begin{array}{l}\text { Number of } \\
\text { diaspores per } \\
\text { flower }\end{array}$ & $1 d, 5 d^{*}$ & Quantitative & $\begin{array}{l}1 ; 2 \text { to } 5 ; \text { more } \\
\text { than } 5\end{array}$ & $\begin{array}{l}\text { Dispersal, } \\
\text { persistence }\end{array}$ & $\begin{array}{l}\text { Reproductive } \\
\text { output }\end{array}$ & Burd et al. (2009) \\
\hline $\begin{array}{l}\text { Number of seeds } \\
\text { per diaspore }\end{array}$ & $1 s, 2 s^{*}$ & Quantitative & $\begin{array}{l}1 ; 2 \text { to } 5 ; \text { more } \\
\text { than } 5\end{array}$ & $\begin{array}{l}\text { Dispersal, } \\
\text { persistence }\end{array}$ & $\begin{array}{l}\text { Dispersal ability, } \\
\text { reproductive } \\
\text { output }\end{array}$ & $\begin{array}{l}\text { Bruun and Poschlod (2006), Duarte } \\
\text { et al. (2007), Leishman (2001), } \\
\text { Westoby et al. (1992) }\end{array}$ \\
\hline Latex & $l a$ & Binary & Present; absent & Persistence & $\begin{array}{l}\text { Herbivory } \\
\text { defense }\end{array}$ & Konno (2011) \\
\hline Stem base & $s t$ & Qualitative & $\begin{array}{l}\text { Single-stemmed; } \\
\text { multi-stemmed }\end{array}$ & Persistence & $\begin{array}{l}\text { Growth and } \\
\text { space holding }\end{array}$ & $\begin{array}{l}\text { Müller et al., (2007), Pérez- } \\
\text { Harguindeguy et al., (2013), Weiher } \\
\text { et al. (1999) }\end{array}$ \\
\hline Habit (life form) & $t r, s h^{*}$ & Qualitative & $\begin{array}{l}\text { Tree; shrub; } \\
\text { escandent }\end{array}$ & Persistence & $\begin{array}{l}\text { Growth, spatial } \\
\text { association }\end{array}$ & $\begin{array}{l}\text { Castanho et al., (2012); Pérez- } \\
\text { Harguindeguy et al., (2013) }\end{array}$ \\
\hline
\end{tabular}

* codes after dummy-variable coding: $1 d$ is one diaspore per flower; $5 d$, more than five diaspores per flower; $1 s$ is one seed per diaspore,

$2 s$, two to five seeds per diaspore; $t r$, trees; $s h$, shrubs. 


\section{Figures captions}

Fig. 1. Principal coordinates analysis (PCoA) of (A) dominant (black) and subordinate (grey) species described by 14 traits of dispersal and persistence; and (B) only subordinate species, described by 5 traits (see Table 1 and 2 for codes of traits and species).

Fig. 2. Principal component analysis (PCA) of subordinate species' CWM matrix (see Table 2 for codes of traits). Functional variation among subordinate species was not related to patch identity (dominant species)

Fig. 3. Principal component analysis (PCA) of subordinate relative abundances by patch identity (dominant nurse species). See Table 1 for codes of species. No relationships were found between the five subordinate species and patch identity.

Fig. 4. Single and pairwise spatial correlograms of subordinate species based on relative abundances in 2 ha of a Restinga vegetation. Splines cross-correlograms are shown in the lower triangular portion of the figure. Moran's I cross-correlograms are shown in upper triangular portion. The main diagonal shows single species analyses: spline correlograms were superimposed by Moran's I correlograms. Black dots depicts significant Moran's I; envelopes (gray areas) below or above zero in splines depicts negative and positive spatial structures, respectively. Negative spatial associations were observed at scales of ca. $40 \mathrm{~m}$ between Myrcia and both Erythroxylum and Myrsine, and also between Eugenia and Myrsine. Positive spatial association occurred between Myrcia and Eugenia.

Fig. 5. Bubble graphs showing the relative abundances (between 1 and 60\%) of four subordinate species (a, b, c, d) in each patch within the $100 \mathrm{~m}$ x $200 \mathrm{~m}$ study area. Areas with high abundance of Myrcia vittoriana (b) were almost unoccupied by Erythroxylum subsessile (a) and Myrsine parvifolia (c). By contrast, Eugenia rotundifolia (d) was coexisting in dense patch of Myrcia (b). 


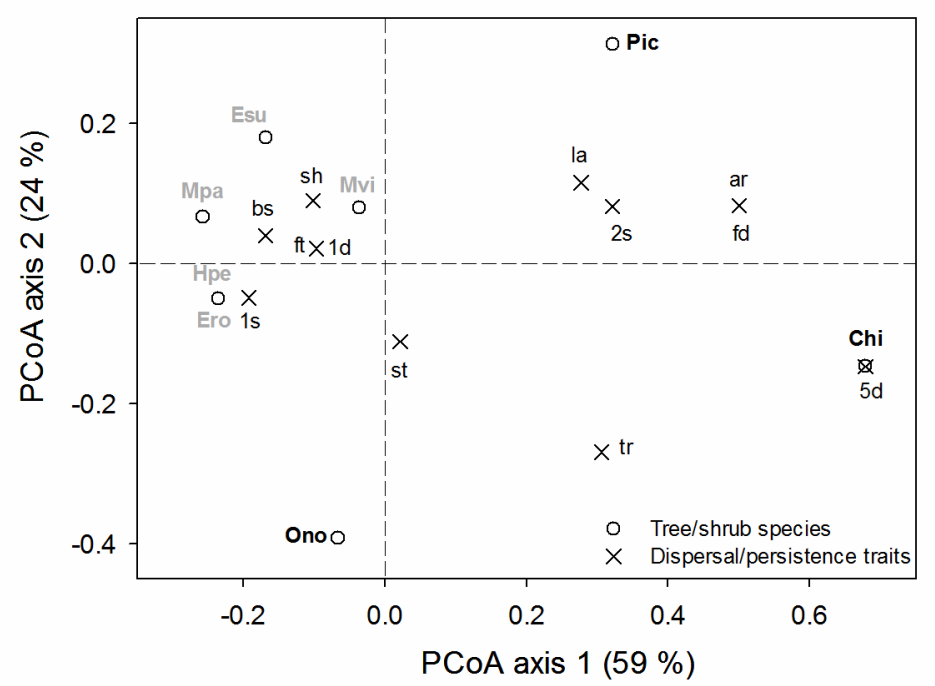

Figure 1a 


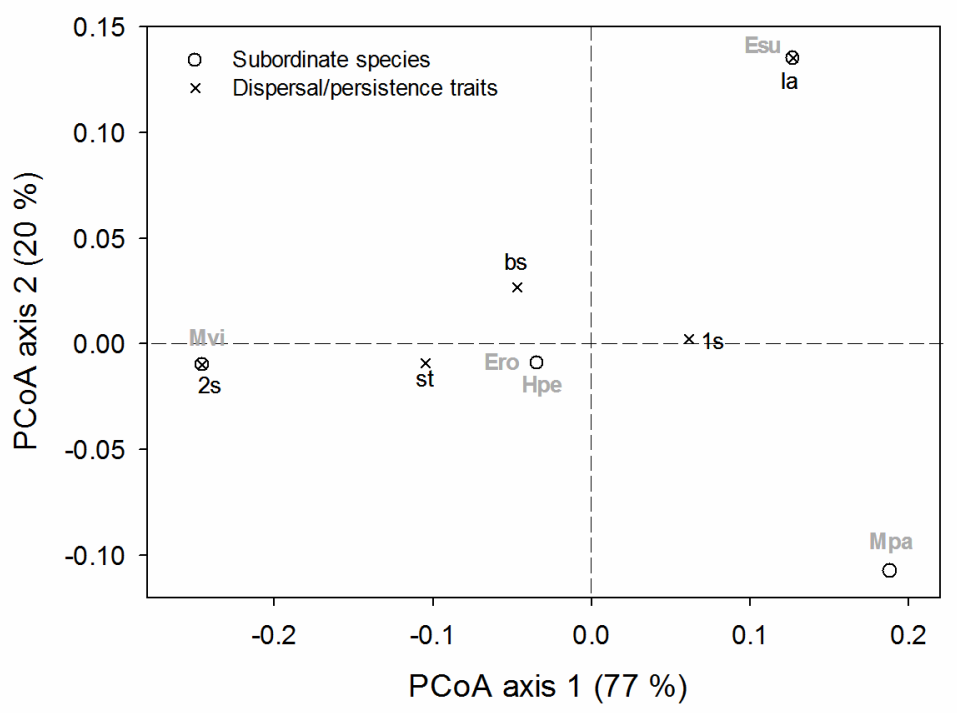

Figure 1b 


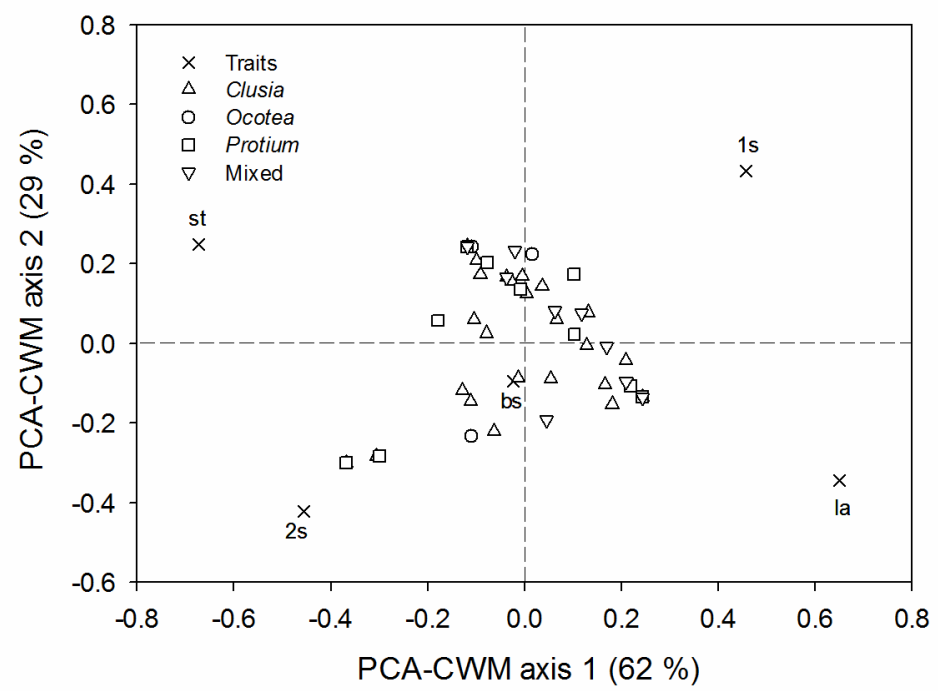

Figure 2 


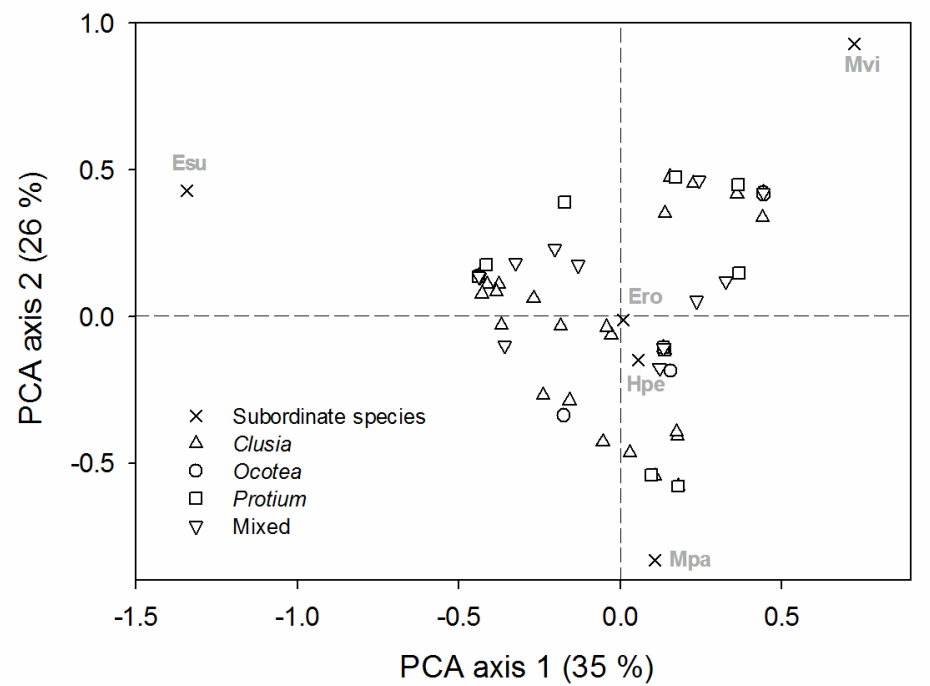

Figure 3 


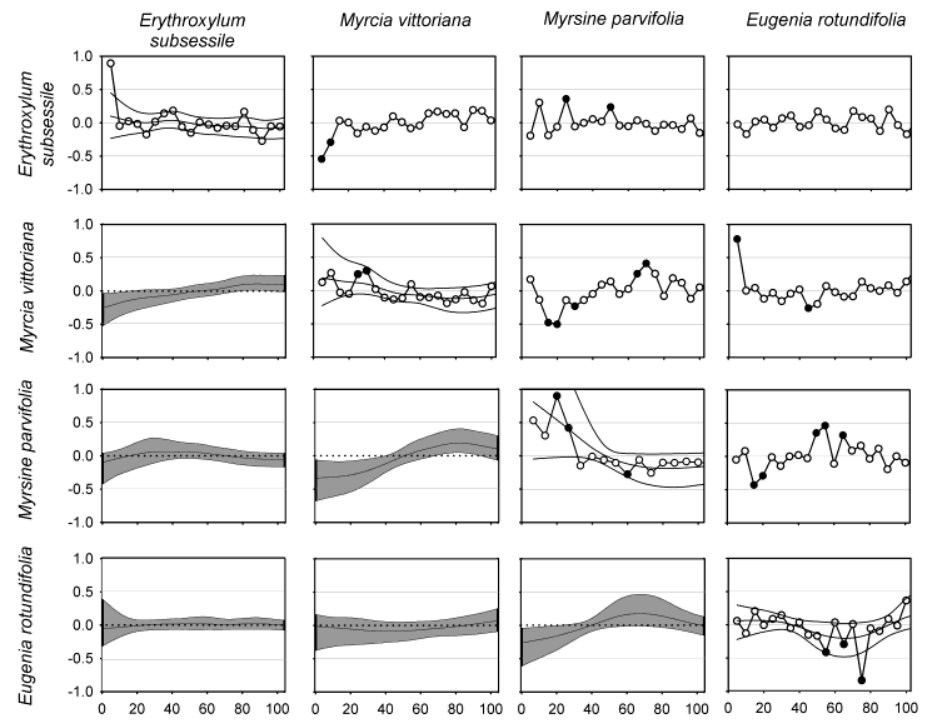

Figure 4 
a) Erythroxylum subsessile

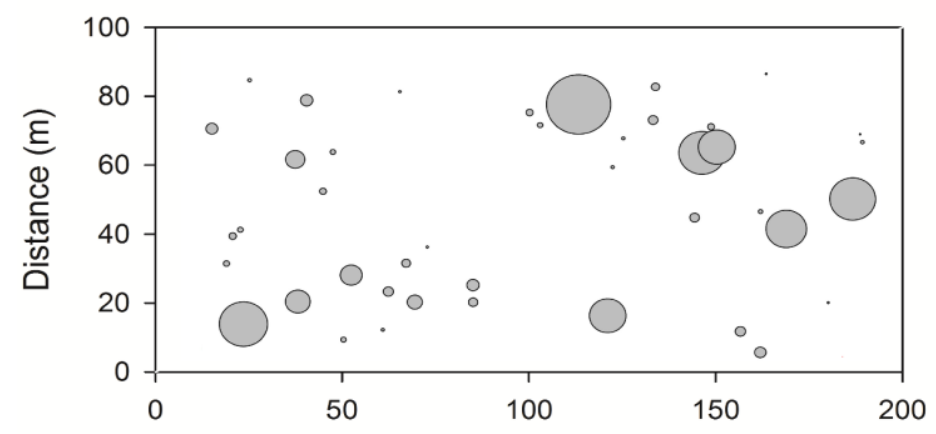

b) Myrcia vittoriana

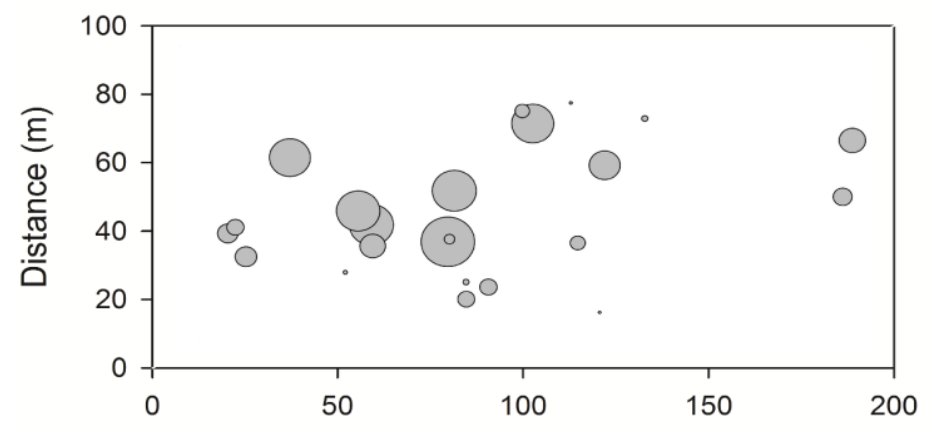

c) Myrsine parvifolia

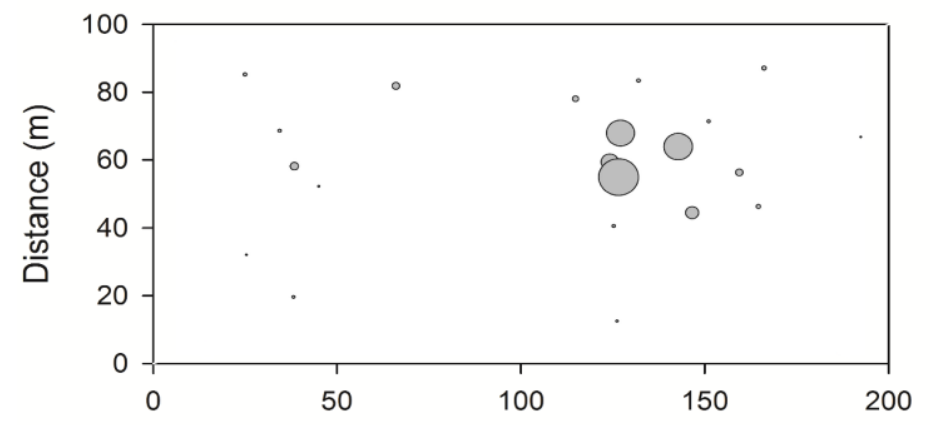

d) Eugenia rotundifolia

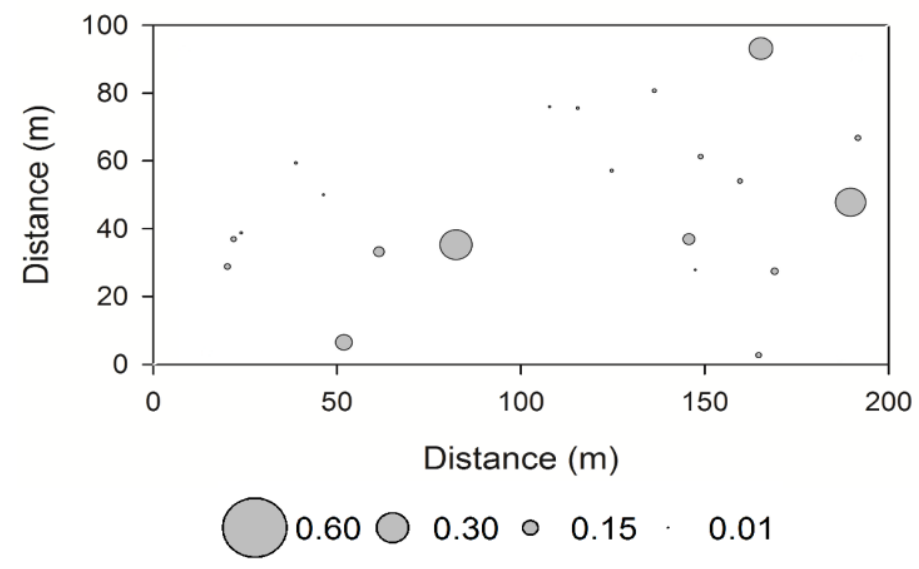

Figure 5 